\title{
ECOLOGICAL VARIETY TRIAL OF ANNUAL FORAGE CROPS IN THE NOVGOROD REGION
}

\author{
Elena Petrovna Shkodina ${ }^{1}$, Olga Vasilyevna Balun ${ }^{1}$, Sergey Ivanovich Kapustin ${ }^{2,3}$, \\ Alexander Borisovich Volodin ${ }^{2}$, Andrey Sergeevich Kapustin ${ }^{4 *}$ \\ ${ }^{I}$ Novgorod Scientific Research Institute of Agriculture, Parkovaya str. 2, Borki, \\ Novgorod region, 173516, Russia; \\ ${ }^{2}$ North Caucasus Federal Agrarian Research Centre, Nikonov str. 49, Mikhailovsk, \\ Stavropol region, 356241, Russia; \\ ${ }^{3}$ Stavropol State Agrarian University, 12 Zootechnicheskiy Ln, Stavropol, 355017, Russia; \\ ${ }^{4 *}$ North Caucasus Federal University, Pushkin str. 1, Stavropol, 355017, Russia; \\ "Corresponding Author Andrey Sergeevich Kapustin, e-mail: hpplus@bk.ru;
}

Received December 2021; Accepted January 2022; Published February 2022;

DOI: https://doi.org/10.31407/ijees12.204

\begin{abstract}
The goal of the research is to study new forage crops, the characteristics of their growth, development, crop formation and identifying the most promising ones for growing in the conditions of the Novgorod Region. The ecological trial of forage sorghum of North Caucasus Federal Agrarian Research Centre selection included: Echinochloa frumentacea of Stapaiz variety, Setaria italica var. mocharicum of Stamoga variety, Setaria italica subsp. italica of Stachumi 3 variety, Sudan grass of Sputnitsa, Zemlyachka, Zlata, Sofiya and Nika varieties, sweet sorghum of Galiya and Larets varieties, hybrids Silosnoe 88 and Yarik, Sorghum-sudangrass hybrids Navigator, Gvardeets, Boyarin, Barin. Hot temperature of June and July accelerated the development and growth rates of plants in July and August. On July 27, the height of sorghum crops increased to 180-210 cm; at the end of August, the studied plants reached a height of 240-270 cm. During the first ten days of September, after-grass of most sorghum species can be harvested after the first cut in the second half of July. On average, during 2020-2021 the fresh yield of Echinochloa frumentacea of Stapaiz variety reached $57.8 \mathrm{t} / \mathrm{ha}$, Setaria italica var. mocharicum of Stamoga variety reached $33.6 \mathrm{t} / \mathrm{ha}$, Setaria italica subsp. italica of Stachumi 3 variety reached $42.6 \mathrm{t} / \mathrm{ha}$ at the end of August. The productivity of Sudan grass during this period was 36.4-59.2 t/ha, Sorghum-sudangrass hybrids - 53-74 t/ha, sweet sorghum - 54.4-116.7 t/ha. During the years of the study, the seeds of Echinochloa frumentacea, Setaria italica subsp. italica and Setaria italica var. mocharicum ripened. The maximum content of crude protein in the dry matter of the mass was obtained from Setaria italica subsp. italica - 9.82\%. The minimum presence of crude fiber (30.3\%) and the greatest number of forage units in one kilogram of feed (0.74) was found in sweet sorghum of Galiya variety. The maximum amount of metabolizable energy $(9.01-9.55 \mathrm{MJ} / \mathrm{kg}$ ) was obtained from sweet sorghum of Galiya variety, Sudan grass of Zemlyachka variety and Sorghum-sudangrass hybrid Navigator.
\end{abstract}

Key words: Echinochloa frumentacea, Setaria italica var. mocharicum, Setaria italica subsp. italica, Sudan grass, sweet sorghum, Sorghum-sudangrass hybrids, green matter, crop yield. 